\title{
Innovation and Industry 4.0 as a part of small state diplomacy
}

\author{
Jana Peterkova ${ }^{1 *}$ \\ ${ }^{1}$ Jan Masaryk Centre for International Studies, Faculty of International Relations, University of \\ Economics, Prague, W. Churchill Sq. 4, 130 67, Prague 3, Czech Republic
}

\begin{abstract}
Innovation and Industry 4.0 are topical issues in the era of globalization in many countries around the world. The article focuses on the international practice of small states and the role of innovation as a topic of their foreign policy and diplomacy. The article aims to evaluate the position of the innovation theme in the portfolio of typical issues of diplomatic practice. The aim is to find out to what extent the attention is paid to innovation concerning the country's economic diplomacy and what the prospects for further development are. In the first part, the text will focus on the theoretical definition of the theme of innovation and its anchoring in the diplomacy of small states. The second part introduces the situation from the practice of small states in a broader perspective and brings examples of successful integration of the innovation theme into the strategic plans of small states. The third part maps the contemporary trends and the presence of innovation diplomacy in Czech practice. Attention will be paid mainly to the national level, both from a strategic and instrumental point of view. Using a comparison of successful examples from abroad with the current situation in Czechia, it is possible to identify critical elements that can contribute to a better understanding of the topic by contemporary Czech practice.
\end{abstract}

\section{Introduction}

Science diplomacy and innovation diplomacy and industry 4.0 are nowadays among the most discussed topics. The process of globalization, the importance of knowledge, and the power of knowledge-driven structures take the issue of science, innovation, and technology and their use by states and other actors in foreign relations into the spotlight. The concentration has shifted from rather neutral collaboration to the defense and fulfilling of the nation's interests in the domain of science and technology [1]. Foremost the topic of innovation has broad connotations to economic diplomacy, especially to the export promotion as a lot of countries search for their way, how to promote their companies. The competitiveness of these companies and their products is one of the crucial aspects, and that is why it is also essential to look and the perspective of the new industrial revolution, which is called Industry 4.0. The

\footnotetext{
*Corresponding author: jana.peterkova@vse.cz
} 
other point is that innovation is closely linked with sustainable development, sustainable and innovative solution to pressing problems of today's world, e.g., environment protection or efficient and innovative use of energy. Be innovative is nowadays evaluated as highly modern and positive, and countries want to be perceived as modern and positive entities.

Small states have limits of their power given by the space, military, or economic power. Such a limitation is called vulnerability [2], and one of the leading foreign policy aims is how to overcome such vulnerability. Soft power is considered as a handy tool, especially for small countries. They can operate in the sphere of cultural, political, economic, and social. An example might be Qatar, whose soft power is often given in connection with efforts to ensure through visibility on the international stage their safety [3].

This article focuses on the introduction of innovation diplomacy and its examples in the practice of several small states, including the Netherlands, Denmark, and Switzerland. The article explores the role, possibilities, and limits of science and innovation diplomacy concept in a small state's foreign policy. The text is searching how the position of innovation in small states diplomacy is and which spheres are the most influenced. A particular focus is given to the economic area, economic diplomacy, and the image of the small state, and it's public diplomacy and branding activities. To achieve this aim, documentary analysis is used, focused both on literature and on several case studies. The article analyzes the situation in each chosen country, compares all case studies and formulates possible recommendations for the Czech practice.

\section{Innovation and its role in small states diplomacy}

The space of science and that one of diplomacy and foreign policy are approaching each other, and they get to the center of attention. The world of innovation is based on science and its role in international relations. There are many different definitions of science, which is, in this context, understood as a sum of all knowledge, cultural values, and ethical rules which are accumulated in the process of acquiring new knowledge by using a variety of research methods [4]. Ruffini claims that scientific activities (research) go through the transformation, where we can see four main tendencies. These are:

- the share of research and development on economic activity increases,

- scientific research is increasingly international,

- the center of gravity of global knowledge production moves,

- global issues cannot do without the contribution of science and research [5].

The concept of diplomacy is also changing, and new themes and new types of actors get attention. With this process, it is possible to connect also the area of science and its overlapping with diplomacy, e.g., in economic diplomacy and maintenance of the country's reputation. An example of a specific type of actors can be, for example, diaspora and its contribution to the parent country also in the areas of scientific cooperation, innovation, economic diplomacy, the reputation of the country, or cultural diplomacy [6]. The role of the classic actors such as embassies is also changing, where they focus on their work increasingly on cultural diplomacy, economic cooperation, or just science and innovation [7].

Science can also be seen as a source of soft power, Joseph Nye's concept [8], where international scientific cooperation, even on highly sensitive topics, can smooth mutual relations or give to some state a higher degree of influence. One of the basic terms in science and scientific cooperation is knowledge, and its role has also changed over the years. It broadened from the narrow meaning of scientific knowledge to technology and how knowledge is included in the technology of products or services to its role in innovation, which means the capacity of knowledge to increase the value of new goods or services in the process of innovation [1]. 
Both areas that of science and of diplomacy are changing, and to some extent, they are overlapping. That is where we can see science diplomacy in all its meanings. According to the Royal Society, in the concept of science diplomacy, we can see three different levels:

- "Science in diplomacy - informing foreign policy objectives with scientific advice,

- Diplomacy for science - facilitating international science cooperation,

- Science for diplomacy - using science cooperation to improve international relations between countries." [9].

These terms and definitions became publicly known in 2010 after the joint conference of the Royal Society (UK) and the American Association for the Advancement of Science. Currently, underway also debate about the relationship between the fields of science and international relations, which is the definition of science diplomacy in the spotlight [10].

The concept of innovation diplomacy, in close connection to these definitions, is based on the conviction that science and technology appear nowadays as one of the critical sources for developed and developing countries as well in their contest for competitiveness, which is also connected with the increasing value of knowledge. From broader perspective "(...) innovation diplomacy encompasses the concept and practice of bridging distance and other divides (cultural, socioeconomic, technological, etc.) with focused and properly targeted initiatives to connect ideas and solutions with markets and investors ready to appreciate them and nurture them to their full potential." [11]. Innovation diplomacy, in this context, also encompasses science and technology diplomacy, but in some cases (e.g., The Netherlands), the term of science, technology, and innovation (STI) diplomacy is used, which enables the description in a more detailed way. This text will use the term innovation diplomacy as an umbrella concept also for branches of science or technology diplomacy.

Innovation diplomacy is essential not only for EU member states but also for the European Union itself. The European Commission expressed its interest in supporting international cooperation in research and innovation and also sees study innovation diplomacy as an important tool of its soft power and foreign policy [12]. The importance of collaboration in science, technology, and innovation is mentioned and also recognized by a number of international organizations, primarily the UN, which, in its Agenda for Sustainable Development in 2030, indicates the essential role of science in international cooperation. This applies not only to the UN but also to a number of other cooperating organizations and institutions, such as UNESCO [13].

\section{Innovation diplomacy - examples from practice}

Innovation is now considered to be an inseparable part of sustainable development. Science, technology, and innovation are seen as a form of soft power, which they can use even small states. However, also if it is necessary to provide sufficient financial resources, intellectual wealth does not derive directly from the hard-power resources. Small states aware of this fact and innovation are considered to be one of the ways to promote the wealth of the country, for example, in connection with economic diplomacy, as well as improve the country's reputation and its image in the international environment.

To render the current situation, The Netherlands, Denmark, and Switzerland were chosen as successful examples of innovation diplomacy in practice. A closer look at their practice draws key trends, tools, and types of actors, who are involved in innovation diplomacy. 


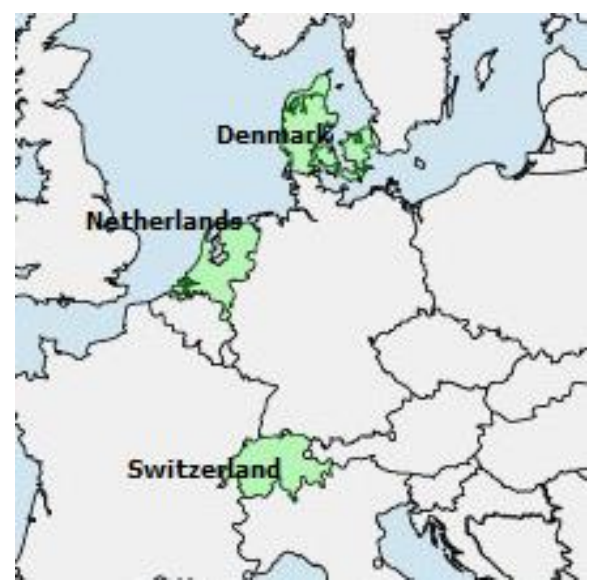

Fig 1. Map of the Netherlands, Denmark, and Switzerland

The situation in individual countries will be approached on the basis of several criteria. The first criterion is actors in innovation diplomacy, both state and non-state eventually. In this category will be examined further coordination system and the presence of actors abroad. Each state has its own system of how to manage its actors abroad. The basic structure can be created by embassies with "innovation" diplomats on selected offices. An important role also belongs to state agencies or specialized institutions devoted to science and innovation if a state decides to create such an office. The second one is the state's interest in innovations that can be expressed by a specific document - a strategy that elaborates on this theme and sets goals for the activities of the state. The third criterion, with regard to the country's foreign policy, will link innovation diplomacy to economic diplomacy and the promotion of the country. The question is whether such a link exists and to what level is used by the government for promotion.

\subsection{The Netherlands}

In the Netherlands, the key institution that deals with international science collaboration and science diplomacy is the Netherlands Organization for Scientific Research (NWO), which operates under the auspices of the Ministry of Education, Culture, and Science (MECS). Its role is to coordinate the collaboration among different Dutch partners and institutions and their foreign counterparts. There is also the Advisory Council for Science, Technology, and Innovation (AWTI), which serves as an advisory body to the Government and to the Parliament in areas of science, technology development, and innovation. It has especially strong ties to the Ministry of Education and the Ministry of Economic Affairs (MEA), and its portfolio encompasses both science and innovation policy. According to its statement, its mission should give attention not only to science, technology, and innovation but also to its impact on the economy and society [14]. Ministry of Foreign Affairs and its network of innovation diplomats on embassies and consulates promote and encourage not only Dutch enterprises but also Dutch innovative solutions. As an advisory board also serves the Dutch Trade and Investment Board (DTIB), mainly for the Ministry of Foreign Trade and Development cooperation (MFTD).

Despite the large number of actors who are involved in innovation diplomacy, a number of policies and documents in this area, which were processed and published, according to a 
report issued by the AWTI in 2018 [15], Netherlands does not have an overall, overarching strategy that would, for example, has clearly identified priorities at the national level.

Connection of the theme of innovation and scientific cooperation with economic diplomacy and maintenance of the good name of the country is, in this case, very intense. Participating institutions (e.g. NWO, AWTI or Dutch Ministry of Education, Ministry of Foreign Trade or Ministry of Foreign Affairs), all lists in the available materials and on their websites that their goal is to present the Netherlands as a knowledge economy, as an innovative country that is able not only to attract foreign talents but also offering to the world Dutch solutions. This makes this area also intersected with development cooperation or the theme of sustainable development. A related objective is, however, also support the Dutch exports and efforts to maintain its excellent position in the global innovation index.

\subsection{Denmark}

Denmark creates an exciting picture of the role of innovation in its policy and practice. The leading role belongs to the government and in particular, to the Ministry of Foreign Affairs (MFA), which is engaged in innovation and economic diplomacy as well. In collaboration with the Ministry of Higher Education and Science (MHES), the ministry created an exclusive network of Denmark Innovation Centers, which are located in seven innovative world regions (Seoul, Shanghai, Silicon Valley, Tel Aviv, New Delhi, Sao Paulo, and Munich). The other incorporated institution is the Invest in Denmark agency for investment promotion with the general aim to contribute to higher competitiveness of Danish companies.

Denmark doesn't have a specific innovation strategy, but innovation and innovation diplomacy has its role in Danish Foreign and Security Policy Strategy 2019-2020 [16] and also in the Government Strategy for Economic Diplomacy [17]. Knowledge, innovation, and technology are explicitly mentioned among the main objectives of this strategy with the aim of strengthening of Danish leadership position in this area. Denmark also has its specialty in Techplomacy, when the first techplomat (the official title is Ambassador for Technology and Digitalization) was appointed to Silicon Valley in 2017 [18]. Techplomacy was presented in the previous foreign policy strategy for 2017-2018 as one of its priorities. From the Danish perspective, innovation is connected not only to economic diplomacy but also to development cooperation.

The connection to economic diplomacy is rather clear, and through its successes, in these areas, Denmark also promotes its reputation in the world as an innovative and competitive country with a strong bond to sustainable development.

\subsection{Switzerland}

Switzerland has a long tradition in science diplomacy. The government sent its first science diplomat to the USA in 1958. A concentrated interest in science and innovation is in Switzerland motivated by its existence as a small state with a lack of natural resources on which it would be possible to establish the prosperity of the country. So its brainpower remains one of the critical resources for the country's prosperity [19]. Science diplomacy is in Swiss practice also closely linked with the foreign policy of Switzerland to the EU, or rather EU foreign policy towards Switzerland, as they did in 2014 when the EU limited the access of Switzerland to the Program Horizon 2020 as a result of the crisis around the Croatia protocol [20].

The key actor in the Swiss science and innovation diplomacy is the Federal government and in its structure The Federal Department of Economic Affairs, Education and Research (EAER). Research is considered to be one of the government's priorities and also its promotion. Among federal offices in the State Secretariat for Education, Research and 
Innovation (SERI), and among federal agencies of the EAER, Innosuisse - Swiss Innovation Agency. The Federal Act on the Promotion of Research and Innovation from 2012 established the basic structure of Swiss institutions responsible for the promotion of research and innovation. The structure is created by the Swiss National Science Foundation (SNSF), the Swiss Academies of Arts and Sciences, and Innosuisse. All these institutions are supported by SERI. Swiss innovation presence abroad is performed by the Swiss State Secretariat for Education and Research in cooperation with the Federal Department of Foreign Affairs (FDFA). The network consists of twenty Science and Technology Offices (STO) and Counselors (STC) based at Swiss embassies who closely collaborate with the Swissnex network (five offices) located in world-leading technology hubs, e.g., Boston, Shanghai or Bangalore. The whole system operates under the supervision of the Federal Department of Foreign Affairs. The network is also an excellent example of a public and private partnership.

The Federal Act of the Promotion (2012) can be seen as an actual basic legal norm for promoting innovation, but there are also other strategies. The latest one is Switzerland's International Strategy on Education, Research and Innovation, a strategy of the Federal Council from July 2018. According to this document, activity in research and innovation, including its promotion, is more and more important for Swiss foreign policy and its visibility at the international scene.

The interconnection of science, technology, and innovation with economic diplomacy, society's wellbeing, and also the promotion of the country and fostering its position as an innovation leader is evident. Switzerland's attitude to innovation and its connection with the promotion of the country can be seen as an example and perhaps a model for other small developed countries, who has the ambition to be considered as an innovative country.

\section{Contemporary trends - Czech limits and possibilities}

Following previous case studies, it is possible to identify several trends in innovation diplomacy, how states react to changes in the international environment. The state's role is crucial, especially in the development of environment framework, prioritization, and financial framework. A concrete expression is usually a national strategy for the development of innovation diplomacy, hence the innovation as such. Also important is the identification of key stakeholders, where the state plays a crucial role again. Although an intensive partnership with the private sector is also needed. An interesting example is the implementation of public-private partnerships in the Swiss practice.

Table 1. Trends in innovation diplomacy practice

\begin{tabular}{|l|l|l|l|l|}
\hline & Czechia & Denmark & Netherlands & Switzerland \\
\hline $\begin{array}{l}\text { Special } \\
\text { Innovation }\end{array}$ & $\begin{array}{l}\text { Innovation } \\
\text { Strategy of the } \\
\text { CR 2019-2030 }\end{array}$ & $\begin{array}{l}\text { No (part of } \\
\text { foreign policy } \\
\text { and economic } \\
\text { diplomacy } \\
\text { strategies) }\end{array}$ & $\begin{array}{l}\text { It does not } \\
\text { exist. }\end{array}$ & $\begin{array}{l}\text { The Federal Act } \\
\text { on } \\
\text { Promotion of } \\
\text { Research and } \\
\text { Innovation }\end{array}$ \\
\hline Actors & Government & $\begin{array}{l}\text { Government } \\
\text { MFA, MHES }\end{array}$ & $\begin{array}{l}\text { Government } \\
\text { MFA, MEA }\end{array}$ & $\begin{array}{l}\text { Federal Council } \\
\text { EAER, SERI } \\
\text { CRDI }\end{array}$ \\
& MIT & $\begin{array}{l}\text { Denmark } \\
\text { Innovation } \\
\text { MFA }\end{array}$ & MECS & Swissnex, \\
& Centres & NWF, \\
Techplomat & AWTI & Innosuisse \\
& STO, STC \\
\hline
\end{tabular}




\begin{tabular}{|l|l|l|l|l|}
\hline & & DTIB & \\
\hline $\begin{array}{l}\text { Connection to } \\
\text { the country's } \\
\text { reputation }\end{array}$ & $\begin{array}{l}\text { Strong (one of } \\
\text { the priorities in a } \\
\text { special } \\
\text { innovation } \\
\text { strategy) }\end{array}$ & $\begin{array}{l}\text { Yes } \\
\text { connection with } \\
\text { development } \\
\text { cooperation) }\end{array}$ & $\begin{array}{l}\text { Yes } \\
\text { connection } \\
\text { with } \\
\text { economic } \\
\text { diplomacy) }\end{array}$ & $\begin{array}{l}\text { Strong (special } \\
\text { legal norm - The } \\
\text { Federal Act) }\end{array}$ \\
\hline
\end{tabular}

Source: author

The Czech situation is a little bit different compared to the above-mentioned countries. All of them belong to innovation leaders, and their goal is to maintain such a reputation. Czechia, on the other hand, intends using innovative strategies to improve her position and become such an innovative leader. One of the objectives of the Czech Innovation Strategy 2019-2030 is to get Czechia among the twenty most innovative countries in the world [21].

The Czech government gives innovation and its connection with international competitiveness, its full attention. Not only is the government itself, but they're also a special Council for Research, Development, and Innovation (CRDI), who should be the central coordination body for science and innovation. A privileged position belongs to the Ministry of Industry and Trade (MIT), as innovation is seen in close connection with the international competitiveness of the Czech economy. The Ministry of Foreign Affairs (MFA) focuses on the promotion of excellent results of Czech science and research, as well as the presentation of the Czech innovative solutions. To the group of collaborating partners also belong the agency CzechInvest, mostly concentrated on foreign direct investment in Czechia.

Innovation in Czech practice is associated with both economic diplomacy, through the support of research and development results and attracting investments with high added value, but also with the maintenance of a good name, which is called "smart marketing" directly as one of the pillars of the Czech innovation strategy.

\section{Conclusion}

Science, innovation, and technology is a relevant and topical issue of today's society and even in international relations and foreign policy. The ability to innovate is one of the significant sources of soft power. For small states is an area of innovation welcome opportunity to improve their status in the international community. The examples show small States are aware of this potential, and many of them have successfully developed. Innovative Diplomacy in their practice firmly connected to both economic diplomacy, as well as to care for the good name of the country. The topic is also essential for the Czech Republic, but the situation is different in relation to the current position of innovations in individual countries. While the Netherlands, Denmark, and Switzerland are among the innovative leaders, Czech must work very hard to improve their situation and shift among the twenty most innovative countries in the world.

\section{References}

1. J. Leijten, Exploring the future of innovation diplomacy, European Journal of Futures Research 5, 20 (2017)

2. C. Archer, A. J. K. Bailes, A. Wivel (eds.) Small States and International Security: Europe and Beyond (Routledge, London, 2014)

3. P. M. Brannagan, R. Giulianotti, The soft power - soft disempowerment nexus: the case of Qatar, International Affairs 94, 1139-1157 (2018)

4. V. Turekian, The Evolution of Science Diplomacy, Global Policy 9, 5-7 (2018) 
5. P.- B. Ruffini. Věda a diplomacie. Nový rozměr mezinárodnich vztahů. (Academia, Praha, 2018)

6. D. Stone, E. Douglas, Advance diaspora diplomacy in a networked world, International Journal of Cultural Policy 24, 710-723 (2018)

7. A. Cooper, J. Cornut The changing practices of frontline diplomacy: New directions for inquiry. Review of International Studies 45 , 300-319 (2019)

8. J. S. Nye, Soft Power and Public Diplomacy Revisited. The Hague Journal of Diplomacy 14, 7-20 (2019)

9. Royal Society, New Frontiers in Science Diplomacy. Navigating the changing balance of power. (The Royal Society, London, 2010)

10. C. Kalthofen, M. Acuto, Science Diplomacy: Introduction to a Boundary Problem, Global Policy 9, 8-14 (2018)

11. E. Carayannis, D. F. J. Campbell, Open Innovation Diplomacy and a 21st Century Fractal Research, Education and Innovation (FREIE) Ecosystem: Building on the Quadruple and Quintuple Helix Innovation Concepts and the "Mode 3". Knowledge Production System 3, 327 (2011)

12. J. Leijten, Innovation policy and international relations: directions for EU diplomacy. European Journal of Future Research 7, 4 (2019)

13. F. Schlegel, Science for Global Understanding, Science 358, 699-699 (2017)

14. AWTI, Advisory Council for science, technology and innovation. (2019) https://english.awti.nl/

15. AWTI, STI Diplomacy. Advancing the Internationalization of Science, Technology and Innovation. (2019) https:/www.awti.nl/documenten/adviezen/2017/05/16/vertaling-stidiplomacy

16. The Danish Government, Foreign and Security Policy Strategy, (2019) https://www.dsn.gob.es/sites/dsn/files/2018_Denmark\%20Foreign\%20and\%20security \%20policy\%20strategy\%202019-2020.pdf

17. The Ministry of Foreign Affairs, Government Strategy for Economic Diplomacy. (2019) https://thetradecouncil.dk/en/about-us/strategy.

18. Office of Denmark's Tech Ambassador, Techplomacy, (2019) https://techamb.um.dk/en/Techplomacy/

19. F. Schlegel, Swiss Science Diplomacy: Harnessing the Inventiveness and Excellence of the Private and Public Sectors. Science and Diplomacy, Vol. 3, No. 1 (2014).

20. M. Leese, Between a Carrot and a Stick: Science Diplomacy and Access to EU Research Funding, Global Policy, 9, 48-52 (2018)

21. The Government of the CR. Czech Innovation Strategy 2019 - 2030, https://www.vlada.cz/assets/urad-vlady/poskytovani-informaci/poskytnute-informacena-zadost/Priloha_1_Inovacni-strategie.pdf 